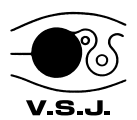

\title{
MRIによる水蓄熱用カプセル充てん層内の局所熱流束分布計測*
}

\author{
小川 邦康 ${ }^{1}$, 別宮 光洋 ${ }^{2}$, 長谷川 浩巳 ${ }^{3}$, 橋本 克巳 ${ }^{3}$, 平井 秀一郎 ${ }^{4}$
}

\section{MRI Measurement of Local Heat Flux Distributions in Packed Bed of Ice Thermal Storage Capsules}

\author{
Kuniyasu Ogawa, Mitsuhiro BecK, Hiromi HaSegawA, Katsumi Hashimoto and Shuichiro HIRAI
}

\begin{abstract}
A new method to measure local heat flux distribution from capsule surface in packed bed of ice thermal storage capsule using magnetic resonance imaging (MRI) was developed to investigate nonuniform heat transfer phenomena in porous media. In this method, local heat flux distribution from a capsule was calculated from freezing rate of water in the capsule cooled by brine below $0{ }^{\circ} \mathrm{C}$ in a time interval. The mean heat flux of single capsule surface under uniform flow obtained by this method agrees with one by the conventional method. By applying this method to packed bed, heat flux distributions on capsule surfaces in packed bed were measured, and axial velocity distributions of brine through packed bed were obtained by the phase method in MRI techniques. Based on these results, it was found that heat exchange effectiveness of brine through channel was lower than that through the region where channel flow was not induced. In addition, time-variations of overall heat transfer coefficient of packed bed at different flow rates were obtained.
\end{abstract}

Keywords: Ice thermal storage, Magnetic resonance imaging, Local heat flux measurement, Freezing

\section{1 . 緒 論}

水蓄熱用球状カプセル充てん層の蓄・放熱特性を向上さ せるには, 入口・出口温度差による蓄熱槽全体での伝熱特 性を把握するだけではなく，充てん層内の不均一流動によ る局所熱伝達分布をも考慮して, 流路構造やカプセル充て ん構造などを設計する必要がある. 球状カプセルをランダ ムに充てんさせた層内では不均質な空隙構造となり，「吹き 抜け」と呼ばれる局所的に高流速領域が形成され ${ }^{1), 2)}$, これ までの均一流動を前提とした充てん層内の粒子一流体間熱 伝達の実験的研究では不均一流動場での局所伝熱特性を適 切に評価できない．このため, 不均質な多孔質内の局所流

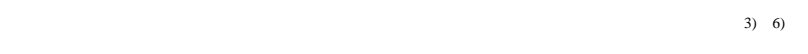

これまでに充てん層内及び蓄熱材内の流動や伝熱特性の 計測が数多く試みられてきた ${ }^{3 \sim 14)}$.これら従来の計測法に 対して, 充てん層内部の空隙構造と共に内部流動場を三次 元的に計測できる新たな手法として磁気共鳴イメージング (MRI) 装置がある ${ }^{15)}$ 16). この MRI を氷蓄熱用球状カプセ ル充てん層の凍結観測に用いれば, 内部空隙構造や流動場 の把握のみならず, カプセル内の水の凍結速度の計測から カプセル表面での熱流束分布を算出することが可能となる． すなわち，MRI 計測によって充てん層内の空隙構造・流動

\footnotetext{
*原稿受付 2000 年5月19日

慶應義塾大学 理工学部

東京工業大学大学院 総合理工学研究科

正会員 電力中央研究所 横須賀研究所

東京工業大学 炭素循環素材研究センター
}

場および局所熱流束分布の把握が初めて可能となる . 本研究では, 熱流束計測の定量性を確認するために，一 樣流中でのカプセル内の凍結挙動を計測し, カプセル内側 壁面から半径方向に進行する水の凍結速度からカプセル表 面での局所熱流束分布を算出した. 产の結果と従来の通電 加熱による測定結果 ${ }^{17)}$ との比較を行なった . また, 本計測 法では生成した水内部での周方向の熱拡散を無視している ため，これによる熱流束計測精度の低下を数值解析を行な うことによって評価した，さらに，この熱流束計測法を力 プセル充てん層内の伝熱計測に適用し, 充てん層内での不 均一流動と局所熱流束分布の計測を行ない, この結果を基 にして充てん層の熱通過率の算出と, 充てん層内の吹き抜 け領域での熱通過有効度の評価を行なった .

\section{2 . 単一カプセルでの熱流束計測}

カプセル内部に充てんされた水は周囲からの冷却によっ て凍結し始め, 水はカプセル内側壁面から中心に向かって 成長する. 球状カプセルに光の中心を原点とするFig. 1(a) に示す球座標系 $(r, \theta, \varphi)$ を適用することによって半径方 向 $r$ の凍結速度からカプセル表面での局所熱流束分布 $q(\theta, \varphi)$ を算出することが可能となる .ここでは, この新 しい熱流束計測法の実験的な定量評価と, カプセル及び水 の内部での $(\theta, \varphi)$ 方向への熱拡散を無視したことによる 局所熱流束計測時の空間分解能および計測精度の低下を数 値解析によって評価した .

本研究では, MRI 装置として Varian 社製 Unity INOVA 300 (7.05T, 内径150mm縦型超伝導磁石, Doty社製傾斜磁 場コイルと内径 $60 \mathrm{~mm}$ のRFプローブ）を使用した . 


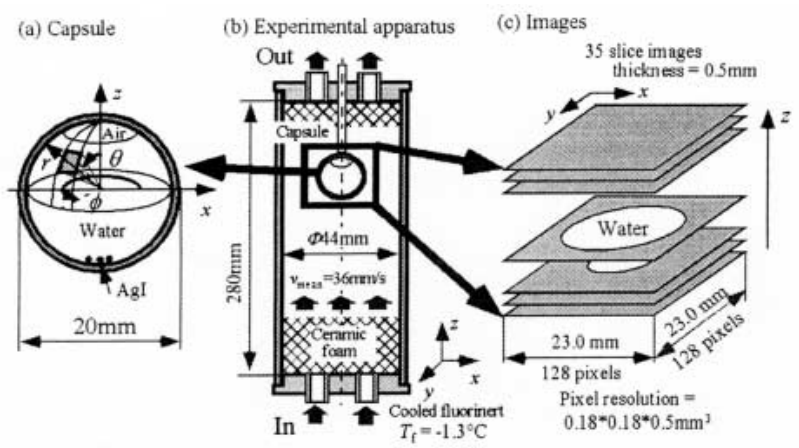

Fig. 1 Schematic of experimental apparatus to measure local heat flux distribution from the surface of single capsule under uniform flow.

\section{1 一樣流中に置かれた球カプセルの局所熱流束計測}

\section{1 実験装置およびMRI計測条件}

直径 $20 \mathrm{~mm}$ の球状ポリプロピレンカプセルを内径 $44 \mathrm{~mm}$ の円管内に配置し, 弚の周囲に温度 $T_{\mathrm{f}}$ の流体を一樣に流す ことによってカプセルを冷却する .この状態でカプセル内 部の水が時間と共に凍結していく樣子をMRIにより計測し た . 用いた実験装置をFig. 1 (b)に，カプセルの形状と内部 充てん物をTable 1に示す。

Table 1 Capsule conditions $(20 \mathrm{~mm})$

\begin{tabular}{ll}
\hline Material & Polypropylene \\
Outside diameter & $19.8 \mathrm{~mm}$ \\
Thickness & $1 \mathrm{~mm}$ \\
Inside packing material & Distilled water $+\mathrm{Agl}+\mathrm{N}_{2}$ \\
Total mass & gas $3.6 \mathrm{~g}$ \\
\hline
\end{tabular}

冷却用流体として水素原子Hを含まないフロリナート (3M製FC-40)を使用し，流動による画像のひずみを最小限 に留めた .凍結を開始させるために冷却用流体の温度 $T_{f}$ を $-3.6^{\circ} \mathrm{C}$ に保ち，過冷却状態のカプセル内部の樣子を高速画 像法(gems)によって15秒毎に観測し続けた .この条件下で は, おおよ光10分程度て過冷却状態が解除され，樹枝状結 晶が MR 画像に現れる.この樹枝状結晶が確認されたら， 直ちに流体の温度を $T_{\mathrm{f}}=-1.3^{\circ} \mathrm{C}$ にまで上昇させ, 実験か終 了するまで保持した この際の流体温度の上昇には約 2 分程 度を要した 。

単一カプセル内の凍結挙動を最も高画質で, しかも多断 面画像での計測が可能な Spin Echo Multi-Slice シーケンス を用いて計測した。主な MRI 計測パラメータをTable 2に， MR画像の断面方向をFig. 1 (c)に示す.

\section{2 球全体での平均熱流束 $\boldsymbol{q}_{\mathrm{m}}$}

凍結開始時刻を $t=0 \mathrm{~s}$ とし, 球の中心を通る水平断面で 取得された MR 画像の一例を時系列でFig. 2に示した . 各 MR 画像は計測開始から終了までの時刻の中間值を代表時 刻 $t$ として表した . 白色の円形領域が水であり, 水及びカ プセルは映らないために黑色で表されている.白色の領域 か時間の経過と共に徐々に小さくなっていく樣子から，力 プセル内壁から徐々に中心に向けて凍結が進行して行き， 水がなくなる $t=6340 \mathrm{~s}$ で涷結が完了したことが分かる.ま た，白色の水領域中に見える線状の黑色部分は過冷却解除 時に生成した樹枝状結晶であり，凍結中に光の形状か変化
Table 2 Acquisition parameters of MRI to measure local heat flux distribution from single capsule in uniform flow.

\begin{tabular}{ll} 
Measured volume $(x, y, z)$ & $23.0 \mathrm{~mm} \times 23.0 \mathrm{~mm} \times 7.5 \mathrm{~mm}$ \\
Pixel number $(x, y)$ & $128 \times 128$ \\
Slice thickness $(z)$ & $0.5 \mathrm{~mm}$ \\
Number of slice & 35 slice images \\
Spatial resolution & $0.18 \times 0.18 \times 0.5 \mathrm{~mm}^{3}$ \\
Acquisition time & $7.5 \mathrm{~min}$ \\
Sequence & Spin Echo Multi-Slice \\
\hline
\end{tabular}

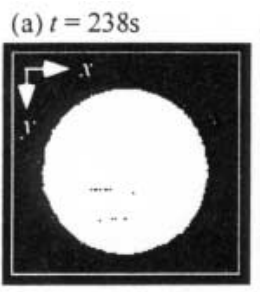
(b) $t=2130 \mathrm{~s}$

(d) $t=4950 \mathrm{~s}$

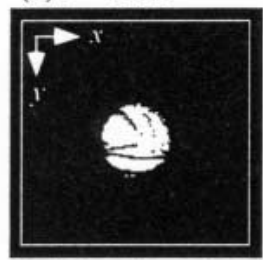

(c) $t=3550 \mathrm{~s}$

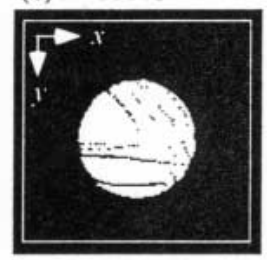

(e) $t=6340 \mathrm{~s}$

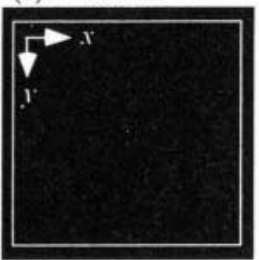

Fig. 2 Obtained images of remaining water in the single capsule at the time $t$.

することはない．

これら時系列の MR 画像を基に各時間 $t$ ごとのカプセル 内全域での残存水分量 $m_{\text {wate }}$ の変化を算出し, 相変化に要す る潜熱量をカプセル表面積で割ってカプセル全体での平均 熱流束 $q_{\mathrm{m}}$ を求めた．弚の結果をFig. 3に示す.この図から 平均熱流束 $q_{\mathrm{m}}$ は, カプセル内の水の成長に伴う熱抵抗の増 加によって時間と共に初め緩やかに減少して行き, 凍結完 了直前でカプセル形状か球形のために熱流束は急激に減少 する .この傾向は神谷ら”の実験結果とほぼ同じであった . また，水による熱抵抗の影響が小さい凍結初期の平均熱流 束 $q_{\mathrm{m}}$ は従来の実験值”とほぼ等しいことから，この手法が 定量的な熱流束の計測法として有効であると言える .

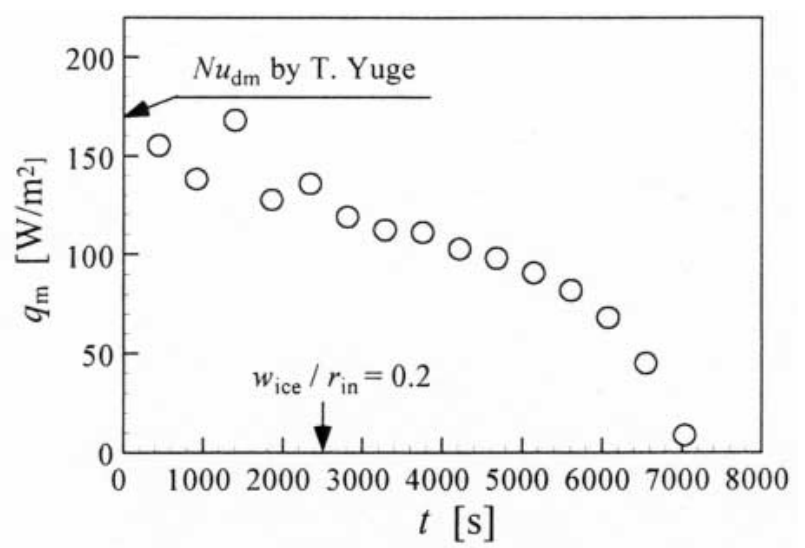

Fig. 3 Time-variation of averaged heat flux $\left(q_{\mathrm{m}}\right)$ over the whole surface of the single capsule. 
(a)

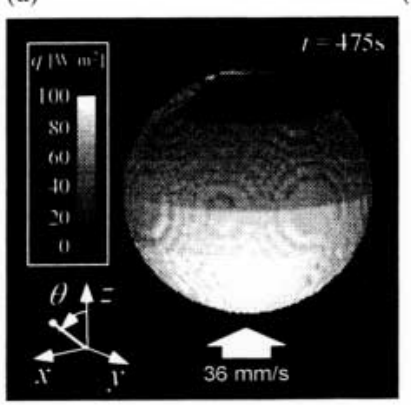

(b)

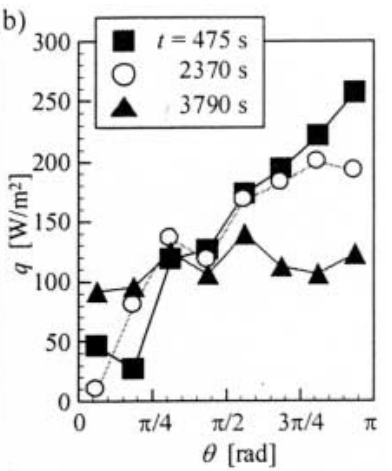

Fig. 4 (a) Local heat flux map $q(\theta, \varphi)$ of the single capsule at $t=475 \mathrm{~s}$, (b) Time-variation of heat flux distributions $q(q)$ averaged over the $\varphi$ direction.

\section{3 局所熱流束分布の計測}

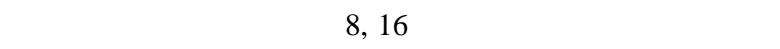
$t=475 \mathrm{~s}$ での局所熱流束分布 $q(\theta, \varphi)$ の三次元表示を Fig. 4 (a)に示す. また， $\varphi$ に対して平均化した熱流束分布 $q(\theta)$ の時間変化をFig. 4 (b)に示す.これらの図より時刻 $t=475 \mathrm{~s}$ におけるよどみ点領域 $(\theta=\Pi)$ での局所熱流束 $q_{\mathrm{stag}}$ は260 W/m²に達し , 計測誤差が大きくなるカプセル上部の 気泡領域 $(\theta=0$ ～$\theta / 4)$ を除いた領域 $(\theta=\Pi / 4 \sim \Pi)$ に 注目しても，下流に行くに従って熱流束が減少していく傾 向を示している. また，熱流束分布 $q(\theta)$ は, 水の熱抵抗 が増加するために，時間と共に低下していく樣子が見られ る .これらの結果から，本計測法によってカプセル表面で の局所熱流束分布の傾向が適切に計測されていることが分 かった .

22 半径方向凍結速度を基にした局所熱流束算出法の誤 差評価

上記の局所熱流束算出法では, $(\theta, \varphi)$ 方向の熱拡散を 無視して,半径 $(r)$ 方向の凍結速度から球カプセル表面での 熱流束分布を算出した .この算出法ではカプセル内壁から の水が成長し，厚くなった場合には $(\theta, \varphi)$ 方向の熱移動 が無視できなくなるために局所熱流束計測の空間分解能お よび計測精度を低下させる．また，上記の熱流束算出法で は, 水内及びポリプロピレン球殼内の顕熱は凍結潜熱に比 べて $1 / 100$ 程度であるために熱移動量からは無視している． ここでは, これらの熱拡散と顕熱の効果か熱流束計測の空 間分解能や測定精度に及ぼす影響を調べるために, Fig. 5

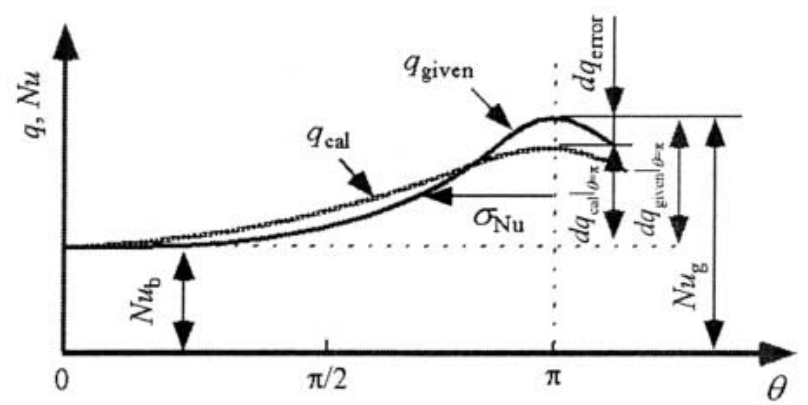

Fig. 5 Heat flux distribution at capsule surface used for error analysis to evaluate the effect of ice thickness due to thermal diffusion in the ice for $q$ direction on the local heat flux measurement.

に模式的に示したように, 球カプセル表面に熱流束分布 $q_{\text {given }}$ を与えて相変化挙動を含めた非定常二次元熱伝導方程 式を解き，これを基に半径 $(r)$ 方向のみの凍結速度から得ら れる熱流束分布 $q_{\text {cal }}$ と与えた熱流束分布 $q_{\text {given }}$ とを比較する ことによって誤差 $d q_{\text {error }}$ の評価を行なった .

\section{1 解析法と誤差の評価法}

この節で行なう解析では, カプセル内部は水で満たされ ており，カプセルは兴の中心を原点とした球座標系で取り 扱え, 過冷却が生ずることなく融点 $\left(0{ }^{\circ} \mathrm{C}\right)$ で速やかに凍結 を開始するとした . また, カプセル外表面では流体によっ てFig. 5に示されている熱流束分布 $q_{\text {given }}$ で冷却されるとし た .この分布 $q_{\text {given }}$ は一樣な又セルト数 $N u_{\mathrm{b}}$ に加えて, よど み点 $(\theta=\Pi)$ を対称軸とした $\theta$ 方向へのガウス分布で表 される $N u$ 数分布によって与えられ, 最大値 $N u_{\mathrm{g}}$ と分散 $\sigma_{\mathrm{Nu}}$ によって表されるガウス分布は, 球周りの物質伝達率 ${ }^{18}$ と の比較から本解析での $N u$ 数分布として近似的に適用がで きるとした .これらの仮定を基に, 水一水及びポリプロピ レン球殻内部での球座標系二次元非定常熱伝導方程式は以 下のように表される .

$$
\begin{aligned}
\frac{\partial\left(\rho_{i} c_{p i} T\right)}{\partial t}=\frac{1}{r^{2}} & \frac{\partial}{\partial r}\left(\lambda_{i} r^{2} \frac{\partial T}{\partial r}\right) \\
& +\frac{1}{r^{2} \sin \theta} \frac{\partial}{\partial \theta}\left(\lambda_{i} \sin \theta \frac{\partial T}{\partial \theta}\right)+S
\end{aligned}
$$

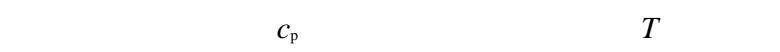
$S$ は相変化の際に発生する潜熱 $L$ を表す発熱項であり, 添 え字iは対象とする範囲よって氷, 水およびポリプロピレン を表す．また，境界条件は対称条件とカプセル外表面での 熱流束値として以下の式を用いた.

$$
\begin{aligned}
& r=0 ; \partial T / \partial r=0 \\
& r=r_{\text {out }} ; q_{\text {out }}=\frac{\lambda_{f} N u\left(T_{f}-T_{\text {out }}\right)}{2 r_{\text {out }}} \\
& \theta=0, \pi ; \partial T / \partial \theta=0
\end{aligned}
$$

ここで, 添え字のoutはポリプロピレン球殼の外表面を， fは冷却用流体を示す. 初期条件は, カプセル内部の水の温

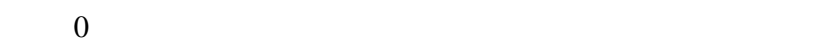
ル外表面から一樣な $N u_{\mathrm{b}}$ により放熱すると仮定して近似的 に得られる温度分布により与えた。

これらの基礎方程式および境界・初期条件を用いて数值 解析を行なう手法として, 水一水界面には VOF 法(Volume of Fluid Method $)^{19}$ を, 熱移動量にはコントロールボリュー ム法 ${ }^{20}$ を用いて差分化を行い, カプセルおよび炎の内部の 温度分布と凍結速度分布を解いた . また, 得られたポリプ ロピレン球殼の温度分布から熱流束分布 $q_{\text {given }}\left(=q_{\text {out }}\right)$ が算出 できる。

水の成長と共に $\theta$ 方向の熱拡散か現れ始め, 半径 $(r)$ 方向 の凍結速度から算出される熱流束分布 $q_{\text {cal }}$ は, Fig. 5の破線 で示したように,与えた熱流束分布 $q_{\text {given }}$ に比べて $\theta$ 方向に 広がり，よどみ点近傍 $(\theta=\Pi)$ での熱流束值が小さくな る .ここでの誤差評価法としてはよどみ点の熱流束に注目 し, 半径 $(r)$ 方向のみの凍結速度から得られる熱流束分布 $d q_{\text {cal }} \mid \Theta=\Pi$ と与えた熱流束分布 $d q_{\text {given }} \mid \Theta=\Pi$ との差 $d q_{\text {error }}$ を 
$d q_{\text {given }} \theta=$ =ாで割つた誤差の割合によって評価を行なった

$$
\frac{d q_{\text {error }}}{\left.d q_{\text {given }}\right|_{\theta=\pi}}=\frac{\left.d q_{\text {given }}\right|_{\theta=\pi}-\left.d q_{\text {cal }}\right|_{\theta=\pi}}{\left.d q_{\text {given }}\right|_{\theta=\pi}}
$$

また，水成長速度を実験と等しくするために，一樣又セ ルト数 $N u_{\mathrm{b}}$ を50, ガウス分布の頂点でのヌセルト数 $N u_{\mathrm{g}}$ を 100 ，ガウス分布の分散 $\sigma_{\mathrm{Nu}}$ を $0.1 \Pi$ から $0.3 \pi$ と仮定して解 析を行なった .

\section{2 解析結果}

よどみ点での熱流束の差 $d q_{\text {error }}$ は 水厚さの薄い凍結初期 には小さいが, 時間の経過と共に水厚さ $w_{\text {ice }}$ が増加して $\theta$ 方向の熱拡散の効果か現れてくるために, 大きくなる .こ こでは , 凍結量の基準として水厚さ $w_{\text {ice }}$ をポリプロピレン 球款の内径 $r_{\mathrm{in}}$ で規格化した值 $w_{\mathrm{ice}} / r_{\mathrm{in}}$ をとり，この凍結率 $w_{\text {ice }} / r_{\text {in }}$ と熱流束の誤差の割合 $d q_{\text {error }} d d q_{\text {given }} \mid \theta=\Pi$ との関係を Fig. 6に示した .この図から， $\sigma$ Nuが小さく，熱流束分布 が急峻であるほど, 弚の誤差は大きくなることが分かる . 球周りの熱伝達と同程度の $N u$ 数分布の分散 $\sigma_{\mathrm{Nu}}$ は $0.3 \pi$ 程 度であり，本計測手法での計測誤差を $20 \%$ まで許容できる とすれば,この図から凍結率 $w_{\text {ice }} / r_{\text {in }}$ が約 0.2 程度まで本計測 手法が適用可能であると言える .この值は前述の熱流束計 測において時刻 $t=2500 \mathrm{~s}$ に対応しており この時刻が本熱 流束計法において熱拡散の影響を無視できなくなる制限値 となる .

また，一樣熱流束分布を与えた場合 $\left(N u_{\mathrm{b}}=N u_{\mathrm{g}}\right)$ に計算さ れる誤差の割合 $d q_{\text {error }} / d q_{\text {given }} \mid \theta=\Pi$ は上記の誤差に比べて非 常に小さいことから顕熱を無視して熱流束分布を算出して も良いことが分かった .また，ここで行なった解析結果は カプセル直径が異なる場合にも適用することができ，後述 する直径 $10 \mathrm{~mm}$ のカプセルであっても $20 \mathrm{~mm}$ のカプセルと 形状が相似であるために熱拡散による測定誤差は同じ程度 となる

\section{3 . カプセル充てん層内の熱伝達計測}

前章の熱流束計測法を球状カプセル充てん層に適用して 充てん層内の局所熱流束分布を計測し，さらに位相法 ${ }^{22,15}$ に よる充てん層内の軸方向流速分布の計測を行った .これら

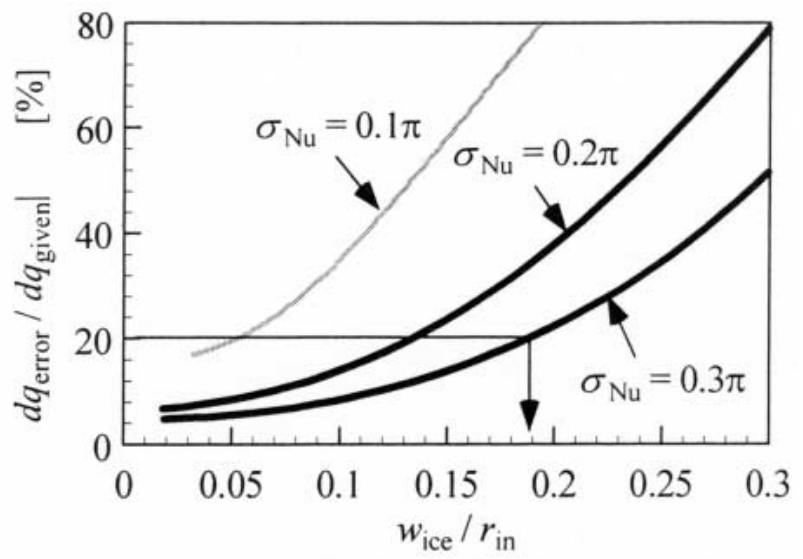

Fig. 6 The relationship between ice thickness and evaluated error of heat flux measurement due to thermal diffusion in the ice for $q$ direction.

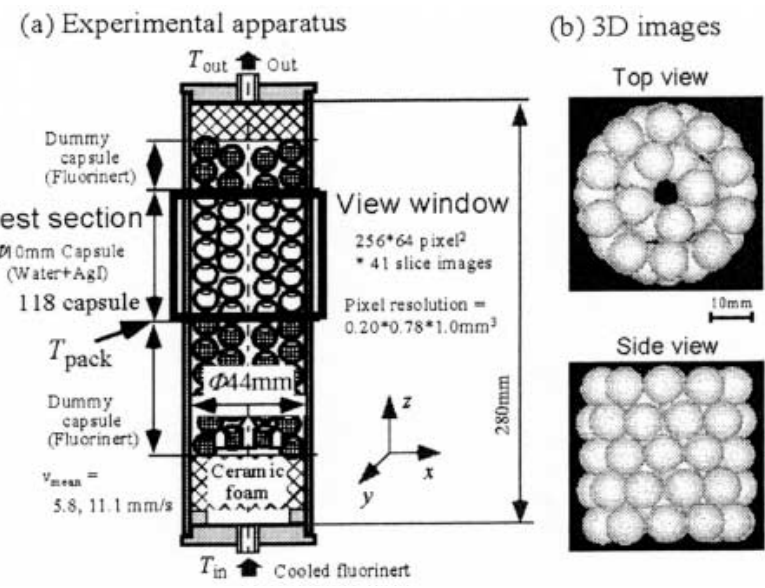

Fig. 7 Schematic of experimental apparatus to measure heat flux map in packed bed of spherical capsules.

の結果を基に充てん層の伝熱特性を表す熱通過率と，不均 一流動を示す吹き抜け領域での熱通過有効度の算出を行 なった。

\section{1 実験装置およびMRI計測条件}

直径が $10 \mathrm{~mm}$ の球状カプセルを内径 $44 \mathrm{~mm}$ の円管内に充 てんし，水蓄熱充てん層とした . 用いた実験装置の概略図 をFig. 7(a)に示す .この充てん層では, 熱流束計測を行な う領域のカプセルのみに蒸留水とヨウ化銀を充てんし, 光 れ以外のカプセルには冷却用流体と同じFC-40を充てんし て凍結潜熱の影響をなくした．水を充てんしたカプセルの 総数は118個であり,弚のカプセル充てん状態がFig. 7(b)に 三次元的に示されている．この上部から見た図から，充て ん層の中心軸付近に軸方向に貫通した大きな空隙があるこ とが分かる . 以後の計測によりこの領域に「吹き抜け」と 呼ばれる高流速領域が形成され，この「吹き抜け領域」と 兴の他の領域での熱流束を比較することにより蓄熱充てん 層としての熱通過有効度の評価を行なった .

ここで行なう蓄熱充てん層内の凍結実験では, 計測領域 内の全てのカプセルを同時に凍結させ , 個々のカプセル内 の凍結挙動から局所熱流束分布を算出する必要がある. 光 こで, 冷却用流体の入口温度 $T_{\text {in }}$ を徐々に $-2{ }^{\circ} \mathrm{C}$ まで下げ, 過冷却状態を保持したままカプセル内の水を予備冷却する 兴の後, 流体温度を急速に-5〜 - $6^{\circ} \mathrm{C}$ に低下させて過冷却 状態を解除し，凍結実験を開始した。ここでは流体温度を

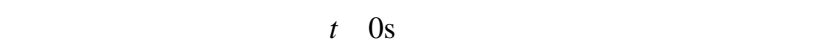
度の低下には約1分程度を要した。

また, 計測領域の近くには熱電対を配置できないため熱 流束計測を行う領域（テストセクション）入口での冷却用 流体の代表温度 $T_{\text {pack }}$ を, 実験装置の周囲から流入する熱量 とダミーカプセルの顕熱量を考慮して推定する必要がある 产の方法として, 予め相変化が生じない温度範囲内での流 体の入口温度 $T_{\text {in }}$ と出口温度 $T_{\text {out }}$ を計測し, 关れらの計測位 置のほぼ真中にある $T_{\text {pack }}$ 位置では温度差の半分, すなわち $\left(T_{\text {out }}-T_{\text {in }}\right)_{\text {Un-freezing }} / 2$ だけ温度が上昇すると仮定した .これより， $T_{\text {pack }}$ は $T_{\text {in }}$ を用いて以下の式により推算される .

$$
T_{\text {pack }}=T_{\text {in }}+\frac{\left(T_{\text {out }}-T_{\text {in }}\right)_{\text {Un-freezing }}}{2}
$$


Table 3 Acquisition parameters of MRI to measure heat flux map of packed bed.

\begin{tabular}{ll}
\hline Measured volume $(x, y, z)$ & $50.0 \mathrm{~mm} \times 50.0 \mathrm{~mm} \times 43.0 \mathrm{~mm}$ \\
Pixel number $(x, y)$ & $256 \times 64$ \\
Slice thickness $(z)$ & $1.05 \mathrm{~mm}$ \\
Number of slice & 41 slice images \\
Spatial resolution & $0.20 \times 0.78 \times 1.05 \mathrm{~mm}^{3}$ \\
Acquisition time & $2.6 \mathrm{~min}$ \\
Sequence & Spin Echo Multi-Slice \\
\hline
\end{tabular}

Table 4 Acquisition parameters of MRI to measure axial velocity map $\left(v_{z}\right)$ of fluid through packed bed.

\begin{tabular}{ll}
\hline Measured volume $(x, y, z)$ & $50.0 \mathrm{~mm} \times 50.0 \mathrm{~mm} \times 41.0 \mathrm{~mm}$ \\
Pixel number $(x, y)$ & $256 \times 256$ \\
Slice thickness $(z)$ & $1.0 \mathrm{~mm}$ \\
Number of slice & 41 slice images \\
Spatial resolution & $0.20 \times 0.20 \times 1.0 \mathrm{~mm}^{3}$ \\
Acquisition time & $2.3 \mathrm{~min}$ \\
Sequence & angio \\
\hline
\end{tabular}

また ここの流体の代表温度 $T_{\text {pack }}$ と凍結温度 $T_{\text {frecing }}\left(=0^{\circ} \mathrm{C}\right)$ との差 $\Delta T$ を以下のように定義した .

$$
\Delta T=T_{\text {freezing }}-T_{\text {pack }}=-T_{\text {pack }}
$$

充てん層内熱流束分布の MRI 計測条件をTable 3に示す 本実験では, 単一カプセル時の実験と比較してカプセル直 径が小さ，流体温度が低いために全カプセルが涷結を完 了するまでの時間が約 30 分と短い．このため，本計測では 空間分解能よりも計測時間の短縮を重視し $y$ 方向の空間分 解能を 4 分の 1 に低下させて, MRI 計測時間を 2 分 40 秒に短 縮した .

充てん層内の空隙を流れる冷却用流体の速度分布計測で は，FC-40に代えて $20 \mathrm{mmol} / /$ 硫酸銅水溶液を等しいレイノ ルズ数で流し，Table 4に示した計測条件により軸方向流速 分布の測定を行なった。

\section{2 局所熱流束 $\boldsymbol{q}$ 分布と軸方向流速 $\boldsymbol{v}_{\mathbf{z}}$ の計測結果}

単一カプセルでの熱流束分布の算出と同樣に, 各カプセ ルの $(\theta, \varphi)$ 方向を弚れ光れ $(4,8)$ 分割して, 半径 $(r)$ 方向 の凍結速度から球力プセル表面での熱流束分布 $q(\theta, \varphi)$ を各時間毎に求めた . 代表時刻 $t=356 \mathrm{~s}$ (平均凍結率 $w_{\mathrm{ic}} / r_{\mathrm{in}}$ $=0.10)$ での充てん層内の各カプセル毎に算出された局所 熱流束分布をFig. 8に示す. 熱流束分布は各カプセル毎に， さらにはカプセルの上流・下流部で異なっており，充てん 層内の熱流束分布は一樣ではないことが分かる. 特に , 充 てん層内の流れによって各カプセル上流部での熱流束が他 の領域に比へて高く示されていることが分かる .

「吹き抜け」が形成されている領域と弚れ以外の領域での 熱流束值の相違を見るために, Fig. 8の局所熱流束分布を 中心軸上の $z y$ 断面で切り，矢印で示した軸方向流速分布と 合わせてFig. 9に示す．さらに，この熱流束・流速分布の 測定結果を中心軸からの距離によって 域に区分し，各領域での平均熱流束と流速の関係をFig. 10 に示した .これらの結果から，中心部の領域Cでは流速が 非常に早く，「吹き抜け」と呼ばれる高流速領域が形成され ており，光の領域ではカプセル表面からの熱流束分布が他 の領域に比べてやや高くなっていることが分かる .このこ

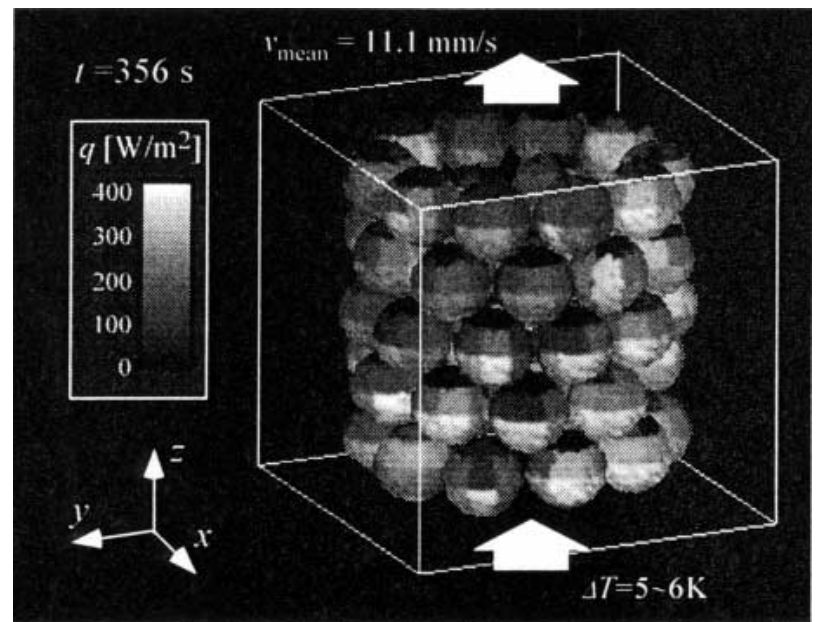

Fig. 8 Heat flux map (q) from each spherical capsule at $\mathrm{t}=$ $356 \mathrm{~s}$ in packed bed.

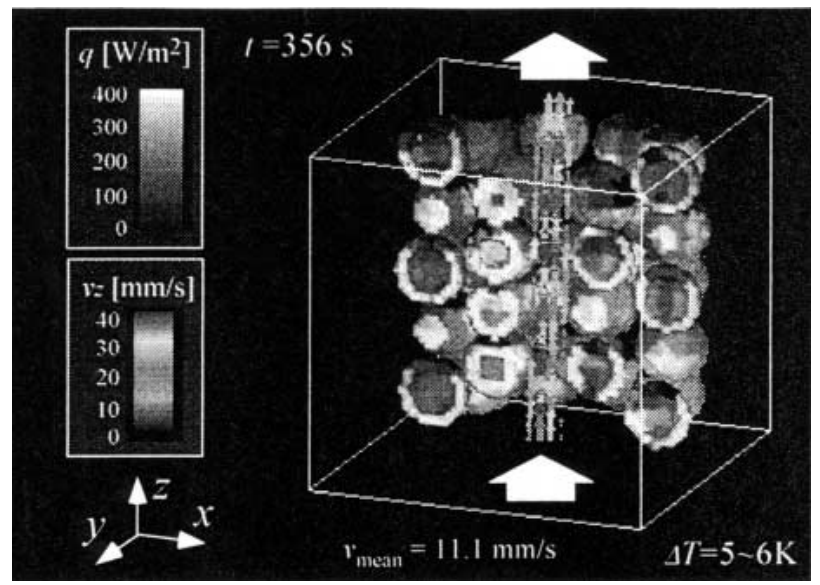

Fig. 9 Sectional heat flux map $(q)$ from each spherical capsule in packed bed at $t=356 \mathrm{~s}$, and axial velocity vector $\left(v_{z}\right)$ of fluid through packed bed.

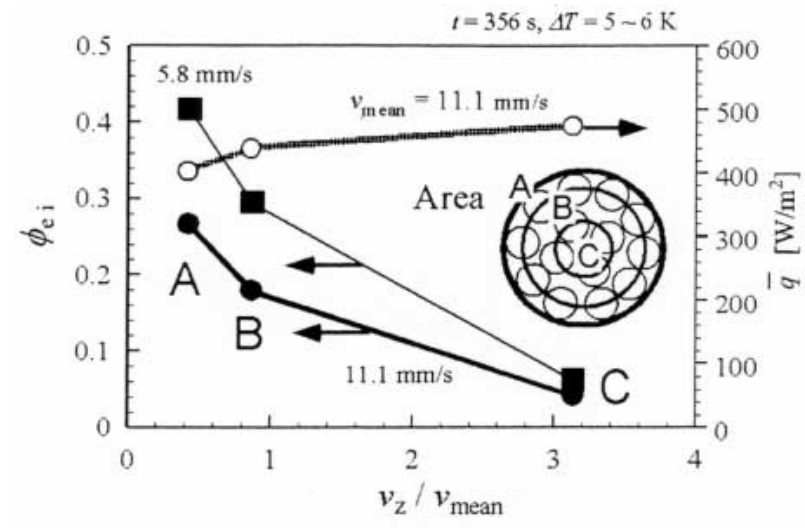

Fig.10 Averaged heat flux $(\bar{q})$ and heat exchange effectiveness $\left(\varphi_{e}\right)$ of brine through each area A, B and C in packed bed at $v_{\text {mean }}=5.8,11.1 \mathrm{~mm} / \mathrm{s}$.

とは, Fig. 9の局所熱流束分布においても中心付近の各力 プセルの熱流束が他の領域に比べて高いことからも見るこ とができる .

3. 3 冷却用流体の熱通過有効度 $\varphi$ elよる評価

Fig. 9に示されている「吹き抜け領域」が蓄熱充てん層 
内に形成されている場合に，この不均一流動が充てん層の 伝熱特性に及ぼす影響を評価するために熱交換器の特性評 価に用いられる熱通過有効度を導入し，各領域での熱通過 有効度の評価を試みた。

各領域を通過する冷却用流体の熱通過有効度 $\varphi_{e i}$ を以下 の式によって定義する .

$$
\phi_{e i}=(\Sigma q S)_{i} / m_{i} c_{p} \Delta T
$$

ここで, $q$ は各カプセル表面位置 $(\theta, \varphi)$ での局所熱流 束，Sは各カプセル表面位置 $(\theta, \varphi)$ での表面積， $m$ は質量 流量， $c_{\mathrm{p}}$ は流体の比熱，添え字 $\mathrm{i}$ はA, B, Cを示す .この式 によって，各領域を通過する冷却用流体の伝達可能な最大 の熱量がカプセル充てん層にどの程度の割合で蓄熱された かを示すことができる .

上式を基に算出された各領域での熱通過有効度 $\varphi_{e i}$ を Fig. 10に示す .この図より吹き抜け領域Cでは平均熱流束 は他の領域に比べて高いものの，熱通過有効度は非常に低 く，「吹き抜け領域」の形成によって充てん層内の熱通過有 効度が大きく低下することが分かる．さらに，冷却用流体 の平均流速 $v_{\text {man }}$ を変化させても「吹き抜け領域」での熱通 過有効度の上昇はほとんど見られず，この「吹き抜け」に よって冷却用流体力蓄熱充てん層と効率的な熱交換をする ことなく通過してしまうことが定量的に示された．

3.4 熱通過率Kによる熱心答性の評価

充てん層内の各領域での熱通過有効度による評価だけで なく，充てん層の蓄・放熱特性の一つとして重要な熱応答 性についても評価を行なった 、ここでは, 冷却用流体の流 入温度による熱流束の差をなくすために流体温度と融点 $(0$ $\left.{ }^{\circ} \mathrm{C}\right)$ との温度差 $\Delta T$ で平均熱流束を除し，充てん層全体での 平均熱通過率 $K$ を以下のように定義して, 平均流速 $v_{\text {mean }}$ の 相違による $K$ の変化を検討した .

$$
K=\bar{q} / \Delta T
$$

二つの平均流速 $v_{\text {men }}=5.8,11.1 \mathrm{~mm} / \mathrm{s}$ での実験から算出さ れた熱通過率 $K$ の時間変化をFig. 11に示す ここで得られ た $K$ の時間変化はFig. 3の分布とは異なり, 時刻 $t=0 \mathrm{~s}$ での 值は小さく，上昇の後に最大值に達する.この相違は，本 実験での冷却開始時刻 $t=0 \mathrm{~s}$ において全てのカプセルがー 斉に凍結を開始する訳ではなく，過冷却状態が解除される までの時間はカプセル毎に異なるため, 過冷却状態を保持

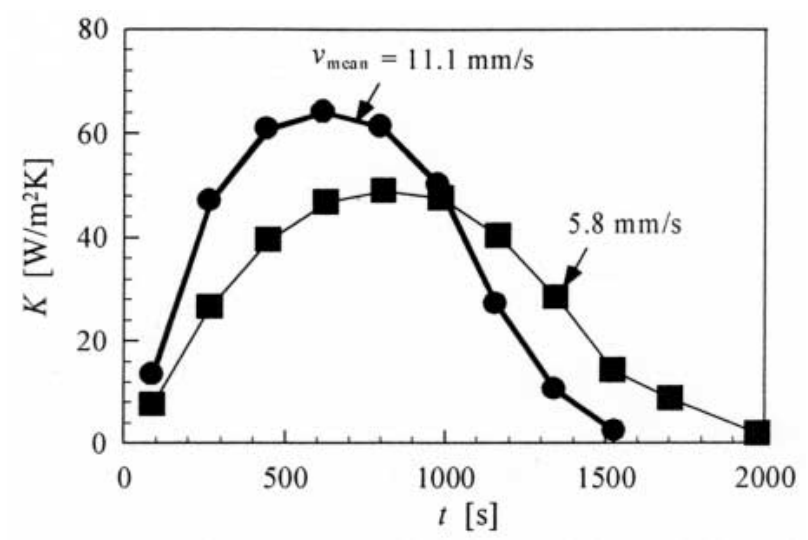

Fig.11 Time-variations of overall heat transfer coefficient $(K)$ over the whole packed bed at $v_{\text {mean }}=5.8,11.1 \mathrm{~mm} / \mathrm{s}$.
しているカプセルでは熱流束 $q$ が見かけ上 0 と算出される ことが原因となって生ずる．

この図より，平均流速 $v_{\text {mean }}$ が大きい場合には高い熱通過 率が得られ，短時間の内に蓄熱充てん層に蓄・放熱するこ とが可能となり，熱応答性が良いことが分かる．したがっ て,Fig. 10及びFig. 11の結果から，熱通過有効度を高くす るには熱媒体を低流速で流動させれば良いが，熱負荷の急 速な変動に対応して迅速に大きな熱量を取り出すには高流 速で流動させる必要があるということが分かる .これらの 定量的な充てん層内部の計測結果を元に，不均一流動に伴 う伝熱特性の評価を行なうことが水蓄熱槽の流路構造, 力 プセル形状や充てん構造などの最適な熱設計を行なうため の重要な指針となると考えている .

\section{4 . 結 論}

カプセル内部の凍結挙動を MRI を用いて計測し，以下に 示す結論を得た .

(1)カプセル内の半径方向凍結速度の計測により, カプセル 表面での局所熱流束分布を定量的に計測することが可 能である . また, 水厚さが熱流束計測の測定誤差に与え る影響についての評価を行なった .

(2)模擬的な水蓄熱用球状カプセル充てん層を製作し, 各力 プセル表面での局所熱流束分布と, 空隙内を流れる冷却 用流体の軸方向流速分布を定量的に計測することがで きた .

(3)計測された局所熱流束及び流速分布より蓄熱充てん層 の熱通過率の時間変化および熱通過有効度が算出され， 高流速領域の「吹き抜け領域」の熱通過有効度が非常に 低いことが定量的に示された .

最後に ここで示したようにMRI を用いて充てん層内部 の局所熱流束計測及び流速計測を行なうことによって，こ れまで定量的な評価が困難であった内部の不均一性をも考 慮した伝熱特性の評価が行なえる可能性があることを付記 する 。

本研究は財団法人電力中央研究所と東京工業大学との共 同研究として行なわれた．また,MRI は東京工業大学炭素 循環素材研究センターの装置を使用した . 関係各位に感謝 の意を表する .

\section{参 考文 献}

1) 国井大蔵 : 熱的単位操作(上), 丸善(1976)，第 4章.

2) 小川邦康, 横内康夫, 平井秀一郎 : 充てん層内流動と空隙構造の 相関 (第一報 : MRIによる軸方向流速分布の計測と軸方向チャ ンネル流の可視化)，日本機械学会論文集(B編), Vol.66, No.642 (2000) pp.445-452.

3) 増岡隆士 : 多孔質内の伝熱, 伝熱研究, Vol. 28, No.108 (1989) pp.147-161.

4) Kunii, D., Suzuki, M. : Particle-to-fluid heat and mass transfer in packed beds of fine particles, Int. J. Heat Mass Transfer, Vol. 10 (1967) pp.845-852.

5) 関信弘, 福迫尚一郎, 宇佐美優, 平賀俊哉 : 水滴冷却を受けた 加熱多孔質層内の伝熱挙動，日本機械学会論文集(B編), Vol. 49, No.448 (1983) pp.2821-2829.

6）稲葉英男・福田武幸 : 球状粒子充てん水平円筒形畜熱槽の非定 常放熱特性，日本機械学会論文集(B編)，Vol. 51, No.470 (1985) pp.3183-3190. 
7) 総論として ,Kaviany, K. : Principles of Heat Transfer in Porous Media, Second edition, Springer (1995).

8) 岩佐薰, 椎名保顕, 稲垣照美 : 蓄熱カプセル内相変化流体の対流 による融解に関する研究, 可視化情報, Vol. 19, No.75 (1999) pp. 41-45.

9) 神谷是行, 栗原茂 : 球カプセル水蓄熱材の蓄・放熱特性 (第1報: 凝固過程の可視化と凝固モデル), 空気調和·衛生工学会論文集, No.67 (1997) pp.67- 74.

10) Sederman, A. J., Johns, M. L., Alexander, P., Gladden, L. F. : Structure-flow correlations in packed beds, Chem. Eng. Sci., Vol. 53, No. 12 (1998) pp.2117-2128.

11) Shattuck, M. D., Behringer, R. P., Johnson, G. A., Georgiadis, J. G. : Convection and flow in porous media. Part 1. Visualization by magnetic resonance imaging, J. Fluid Mech., Vol.332 (1995) pp.215-245.

12) Kutsovsky, Y. E., Scriven, L. E., Davis, H. T. : NMR imaging of velocity profiles and velocity distributions in bead packs, Phys. Fluid, Vol.8, No.4 (1996) pp.863-871.

13) Rajanayagam, V., Yao, S., Pope, J. M. : Quantitative magnetic reso- nance flow and diffusion imaging in porous media, Magnetic Resonance Imaging, Vol.12, No.5 (1995) pp.729-738.

14) Feinauer, A, Altobelli, S. A., Fukushima, E. : NMR measurments of flow profiles in a coarse bed of packed shperes, Magnetic Resonance Imaging, Vol.15, No.4 (1997) pp.479-487.

15)総論として, Callaghan, P. T. : Principles of nuclear magnetic resonance microscopy, Oxford University Press (1991)

16) Reviewとして , Caprihan, A., Fukushima, E. : FLow measurements by NMR, Phys. Reps., Vol.198, No.4 (1990) pp.195-235.

17) Yuge, T. : Experiments on Heat Transfer from Spheres Including Combined Natural and Forced Convection, Trans. ASME, J. Heat Trans., C, Vol.82, No.3 (1960) pp.214-220.

18) Clift, R. J.R. Grace, M.E. Weber : Bubbles, Drops and Particles, (1978) pp.117.

19) Hirt, C. W., Nichols, B. D. : Volume of fluid method for the dynamics of free boundaries, J. Comp. Phys., Vol.39 (1981) pp.201-225.

20) Suhas V. Patankar著,水谷幸夫,香月正司訳 : コンピュータによる 熱移動と流れの数值解析, 森北出版, 1985. 